\title{
IKKa regulates the stratification and differentiation of the epidermis: implications for skin cancer development
}

\author{
Josefa P. Alameda ${ }^{1,2}$, Manuel Navarro ${ }^{1,2}$, Ángel Ramírez ${ }^{1,2}$, Angustias Page ${ }^{1,2}$, \\ Cristian Suárez-Cabrera ${ }^{1,2}$, Rodolfo Moreno-Maldonado ${ }^{3}$, Jesús M. Paramio ${ }^{1,2}$, \\ María del Carmen Fariña ${ }^{4}$, Marcela Del Río, ${ }^{5,6,7}$, María Jesús Fernández-Aceñero8 \\ Ana Bravo9, María de los Llanos Casanova ${ }^{1,2}$ \\ ${ }^{1}$ Molecular Oncology Unit, Centro de Investigaciones Energéticas, Medioambientales y Tecnológicas (CIEMAT), Madrid, Spain \\ ${ }^{2}$ Molecular Oncology, Institute of Biomedical Investigation University Hospital "12 de Octubre", Madrid, Spain \\ ${ }^{3}$ Present address: SILO España, Madrid, Spain \\ ${ }^{4}$ Department of Dermatology, Fundación Jiménez Díaz, Madrid, Spain \\ ${ }^{5}$ Epithelial Biomedicine Division, CIEMAT-CIBERER (U714), Madrid, Spain \\ ${ }^{6}$ Department of Bioengineering, Carlos III University (UC3M), Leganés, Madrid, Spain \\ ${ }^{7}$ Cátedra Fundación Jiménez Díaz (IIS-FJD) of Regenerative Medicine and Tissue Bioengineer, Madrid, Spain \\ ${ }^{8}$ Department of Pathology, Hospital Clínico San Carlos, Madrid, Spain \\ ${ }^{9}$ Department of Veterinary Clinical Sciences, Faculty of Veterinary Medicine, University of Santiago de Compostela, Lugo, \\ Spain
}

Correspondence to: M. Llanos Casanova, email: Ilanos.casanova@ciemat.es

Keywords: IKKa, keratinocyte differentiation, MMP9, skin, skin cancer

Received: July 29, 2016 Accepted: September 29, $2016 \quad$ Published: October 08, 2016

\section{ABSTRACT}

IKKa plays a mandatory role in keratinocyte differentiation and exerts an important task in non-melanoma skin cancer development. However, it is not fully understood how IKKa exerts these functions. To analyze in detail the role of IKKa in epidermal stratification and differentiation, we have generated tridimensional (3D) cultures of human HaCaT keratinocytes and fibroblasts in fibrin gels, obtaining human skin equivalents that comprise an epidermal and a dermal compartments that resembles both the structure and differentiation of normal human skin. We have found that IKKa expression must be strictly regulated in epidermis, as alterations in its levels lead to histological defects and promote the development of malignant features. Specifically, we have found that the augmented expression of IKKa results in increased proliferation and clonogenicity of human keratinocytes, and leads to an accelerated and altered differentiation, augmented ability of invasive growth, induction of the expression of oncogenic proteins (Podoplanin, Snail, Cyclin D1) and increased extracellular matrix proteolytic activity. All these characteristics make keratinocytes overexpressing IKKa to be at a higher risk of developing skin cancer. Comparison of genetic profile obtained by analysis of microarrays of RNA of skin equivalents from both genotypes supports the above described findings.

\section{INTRODUCTION}

The epidermis is a stratified squamous epithelium composed mainly of keratinocytes. Basal keratinocytes proliferate and give rise to differentiated cells, which, upon full maturation, generate the squamous cornified cell layer. Alterations in the normal proliferation/ differentiation equilibrium of the epidermis lead to numerous pathologies, which is important because skin disorders are the most frequent pathologies in humans. Different studies performed in knockout mice for IKK $\alpha$ or in mice with epidermal keratinocyte-specific IKK $\alpha$ ablation have concluded that IKK $\alpha$ is essential for epidermal differentiation [1-4]. IKK $\alpha$ is a member of the 
IKK complex, which is composed of two kinase subunits, IKK $\alpha$ and IKK $\beta$, and a regulatory subunit, IKK $\gamma / \mathrm{NEMO}$. Activated IKK complexes phosphorylate IkB $\alpha$, leading to its ubiquitination and degradation and to the subsequent activation of $\mathrm{NF}-\kappa \mathrm{B}[5,6]$. It has been described that the function of IKK $\alpha$ in epidermis is independent of its kinase activity regulating NF- $\mathrm{B}$ [7], although the early death of IKK $\alpha$ null mice after birth precludes the study of many aspects related to mechanisms through which IKK $\alpha$ controls epidermal differentiation. In this regard, it has been recently proposed that the induction of IKK $\alpha$ has an important role in the pathogenesis of skin diseases that course with altered proliferation/differentiation equilibrium, such as psoriasis [8], suggesting an important role of IKK $\alpha$ in the maintenenace of the homeostasis of the epidermis in humans.

IKK $\alpha$ has also been connected with non-melanoma skin cancer (NMSC), although there are studies that suggest that IKK $\alpha$ may act as a tumor suppressor $[9,10]$ or as a tumor promoter $[11,12]$ in this type of cancer, and this controversy has not yet been solved. Therefore, the development of a new experimental model to decipher the mechanisms through which IKK $\alpha$ regulates the homeostasis of the epidermis and the development of nonmelanoma skin cancer is necessary.

In the present study we have employed a new approach to solve these questions, using a new model of study, based on the generation of $3 \mathrm{D}$ co-cultures of $\mathrm{HaCaT}$ keratinocytes and skin fibroblasts embedded in fibrin gels. These cultures eventually give rise to an ordered structure equivalent to human skin (to which we refer to as skin equivalent), that comprise an epidermal and a dermal compartment that mimic a normal human skin [13]. The spontaneously immortalized human $\mathrm{HaCaT}$ cell line has been widely used in studies related to keratinocytes and epidermal biology because it maintains full epidermal differentiation capacity $[13,14]$. Our previous studies showed that enhanced IKK $\alpha$ expression in HaCaT cells increased both early and terminal differentiation of these cells in differentiation assays in monolayer cultures [12]. However, in these kind of cultures the formation of basal and suprabasal layers is not possible; therefore, they do not allow for the sequential study of the epidermal stratification process. Our present approach using skin equivalents of $\mathrm{HaCaT}$ keratinocytes allows the study, in more physiological conditions, of the contribution of IKK $\alpha$ to the differentiation of the distinct epidermal layers. As a result, we have found that increased levels of IKK $\alpha$ accelerates the differentiation of human keratinocytes, although in an aberrant form, leading to the development of histological defects. In addition, our analysis shows that the augmented expression of IKK $\alpha$ promotes the appearance of preneoplastic changes and the expression of oncogenic proteins in human keratinocytes. The comparison of the genetic profiles obtained by analysis of microarrays of RNA of skin equivalents of both genotypes support these findings. In addition they show the up-regulation in the HaCaT-IKK $\alpha$ skin equivalents of genes also up-regulated in different skin diseases, such as psoriasis and ichthyosis, and in skin cancer. These results highlight the usefulness of our in vitro model of skin equivalents for studying the physiology and disorders of the skin.

\section{RESULTS}

\section{Increased levels of IKK $\alpha$ induces dysplastic changes, disorganized stratification and altered differentiation in human skin equivalents}

We have used the HaCaT-Control and HaCaT-IKK $\alpha$ cell populations of keratinocytes previously described [12] to generate skin equivalents. HaCaT-IKK $\alpha$ cells express the mouse IKK $\alpha$ cDNA under the control of the $\beta$-actin promoter and HaCaT-Control cells contain the empty vector. Both HaCaT-Control and HaCaTIKK $\alpha$ keratinocytes were seeded on a fibrin matrix. Two to three days later they reached confluence and were raised to the air-liquid interface for up to 12 additional days to generate a stratified, differentiated epidermis (confirmed by histological and immunohistochemical analysis). Figure 1A shows the histological appearance of the fibrin organotypic skin equivalent established from HaCaT-Control keratinocytes and cultured for 2-days at the air-liquid interface. As shown, distinctive features that are normally seen in the epidermis in vivo can readily be distinguished, including well-organized and defined epidermal cell layers (basal and suprabasal). Histological resemblance with a human epidermis was also observed in HaCaT-IKK $\alpha$ skin equivalents (Figure 1A). The expression of the transgene in the $\mathrm{HaCaT}-\mathrm{IKK} \alpha$ skin equivalents was verified by western blot and immunohistochemistry (Figure 1B, 1C). The histological analysis showed that HaCaT-IKK $\alpha$ keratinocytes stratified faster than HaCaT-Control cells, as higher number of cell layers were observed in their epidermal compartment from 2-days of air-liquid culture onward (Figure 1A, 1D). Thus, while 2-day skin equivalents of HaCat-Control cells showed one basal and one suprabasal layer (this latter readily distinguished by the presence of keratinocytes with flattened nucleus), in 2-day $\mathrm{HaCaT}-\mathrm{IKK} \alpha$ equivalents there were 3 to 4 cell layers of keratinocytes, organized into three distinct strata: basal stratum (formed by a layer of cylindrical cells containing large nuclei), suprabasal stratum (with 1 or 2 layers of cells with smaller nuclei), and an upper stratum formed by cells with flattened nuclei (Figure 1A). HaCaTControl skin equivalents of 6 to 12 days of differentiation showed 3 to 5 keratinocyte layers. By contrast, the HaCaTIKK $\alpha$ skin equivalents exhibit up to 7-11 layers on day 12 (Figure 1D). In addition, we found that the stratification of the HaCaT- IKK $\alpha$ skin equivalents was disorganized, 
showing disorientated nuclei; they also presented dysplastic keratinocytes in large areas of the epidermis. These defects were similarly detected in the epidermis of transgenic mice expressing exogenously IKK $\alpha$ in the basal layer of the epidermis (K5-IKK $\alpha$ mice) in conditions of hyperproliferation [11]. Areas of spongiosis (intercellular edema of the epithelium) were also detected in the basal as well as in the suprabasal layers of HaCaT-IKK $\alpha$ skin equivalents (Figure 1D), being this alteration also detected in the epidermis of transgenic K5- IKK $\alpha$ mice (data not shown). By contrast, the stratification of HaCaT-Control skin equivalents resembled that of a normal human skin (Figure 1D).

In line with the stratification defects of HaCaT-IKK $\alpha$ keratinocytes in the bioengineered skin, the expression of involucrin (a protein characteristic of suprabasal layers and commonly used as a marker of early epidermal differentiation) was altered in the epidermal compartment of the HaCaT-IKK $\alpha$ skin equivalents, being delocalized along all the keratinocyte layers, including the basal layer (Figure 2A). By contrast, it was correctly localized in the suprabasal layers of the HaCaT-Control skin equivalents, following the pattern of expression observed in the normal human epidermis (Figure 2A). We also observed that the increased expression of IKK $\alpha$ seems to favor the terminal differentiation of keratinocytes, as fillagrin expression (a marker of terminal differentiation) was detected in the upper layer of the HaCat-IKK $\alpha$ skin equivalents of 12-day air-liquid culture, while at this time it was not expressed in the HaCaT-Control fibrin gels (Figure 2A). This result agrees with the presence of markers of terminal differentiation found in monolayer cultures of HaCaTIKK $\alpha$ cells, where corneocytes were detected floating in the supernatant of keratinocytes overexpressing IKK $\alpha$ but not in that of HaCaT-Control cells [12]. Therefore our results show that increased levels of IKK $\alpha$ enhanced the stratification and differentiation of keratinocytes, although in a disorganized, not physiological manner.

\section{Invasive behavior and increased proliferation and clonogenic properties of the HaCaT-IKKa skin equivalents}

In addition to the mentioned altered morphological features, we observed the appearance of invasive foci of keratinocytes growing into the underlying dermal compartment in the HaCaT-IKK $\alpha$ equivalents (Figure 2A, $\mathrm{B}$ arrow). This kind of growth was not observed in HaCaT-Control skin equivalents. We then analyzed the proliferation and apoptosis rates of the keratinocytes, finding that in those areas where the HaCaT-IKK $\alpha$ epidermis had lighter stratification defects, no differences in the number of BrdU positive cells were appreciated between keratinocytes of both genotypes (Figure 2C, 2D).
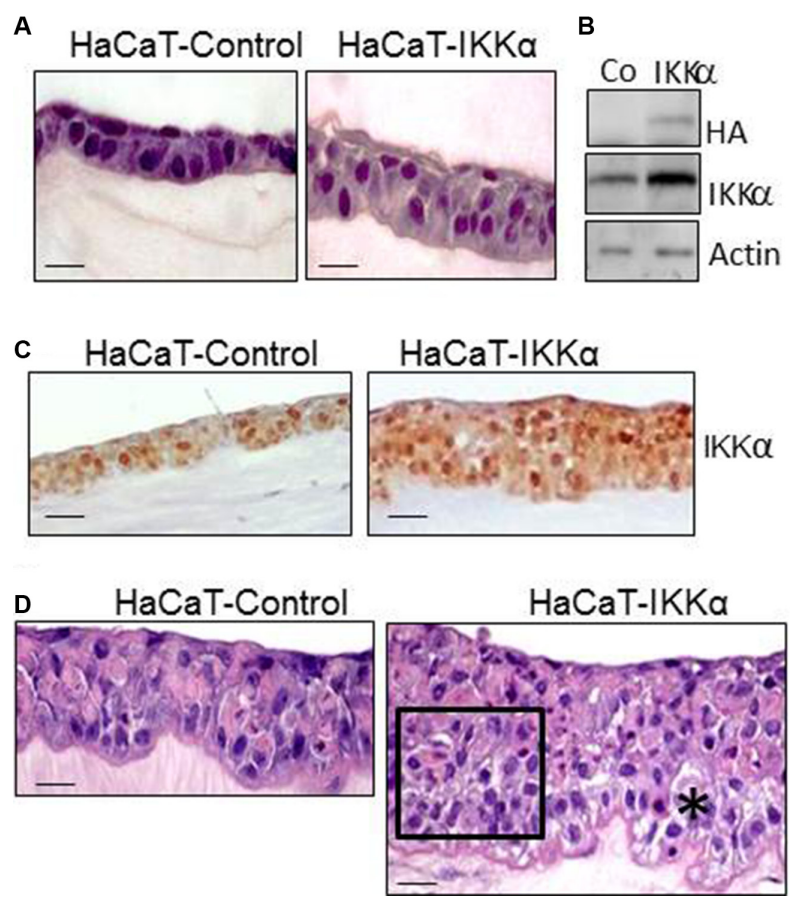

Figure 1: Histological characterization of HaCaT-Control and HaCaT-IKKa skin equivalents. (A) Appearance of skin equivalents after 2 days of differentiation in air-liquid interface culture. Note the increase in the number of keratinocyte layers in the HaCaTIKK $\alpha$ 3D cultures. (B) Western blot showing the expression of the exogenous IKK $\alpha$ in the HaCaT-IKK $\alpha$ skin equivalents (protein extracts derived from 2-day fibrin gels). Actin was used as a loading control. (C) Immunostaining showing IKK $\alpha$ expression in the HaCaT-Control and HaCaT-IKK $\alpha$ skin equivalents using the NB-100-56704 antibody. (D) 12-day skin equivalents showing the increased stratification and marked morphological alterations found in the HaCaT-IKK $\alpha$ cultures. $\left(^{*}\right)=$ area of spongiosis; rectangle $=$ area of disorganized keratinocytes. Scale bar: $30 \mu \mathrm{m}(\mathrm{A}, \mathrm{D}) ; 50 \mu \mathrm{m}(\mathrm{C})$. 
However in those areas of the HaCaT-IKK $\alpha$ epidermal component where the phenotypic alterations were more evident (such as the invagination foci and the regions of higher disorganized stratification), increased BrdU signal was detected (Figure 2E-2G). This result agrees with the increased proliferation seen in keratinocytes of $\mathrm{K} 5$-IKK $\alpha$ mice [11], indicating a strong concordance between data obtained both in vivo in the skin of mice and in the human HaCaT-IKK $\alpha$ skin equivalents. The apoptosis rate was analyzed by cleaved Caspase 3 immunostaining and no differences were found between skin equivalents from the two genotypes of HaCaT cells (data not show).

These characteristics of the HaCaT-IKK $\alpha$ skin equivalents, i.e., altered differentiation, increased proliferation and formation of invasion foci, along with the aberrant morphology of the epidermal compartment may be considered as premalignant signs. To further study the tendency towards malignant transformation of HaCaT-IKK $\alpha$ cells, we performed clonogenicity assays. Examination of the colony forming efficiency showed that HaCaT-IKK $\alpha$ cells produced higher number of colonies than HaCaT-Control cells (Figure 3A). In addition, clear differences were found in colony size: while all of the colonies originated by HaCaT-Control cells were equal or smaller than $2 \mathrm{~mm}$ of diameter, nearly $25 \%$ of the HaCaT-IKK $\alpha$ colonies had a diameter higher than $2 \mathrm{~mm}$ (Figure 3B). We also verified that HaCaT-IKK $\alpha$ cells grown in monolayer cultures exhibited increased proliferation, i.e. after $72 \mathrm{~h}$ of culture HaCaT-IKK $\alpha$ cells grew significantly faster than HaCaT-Control keratinocytes
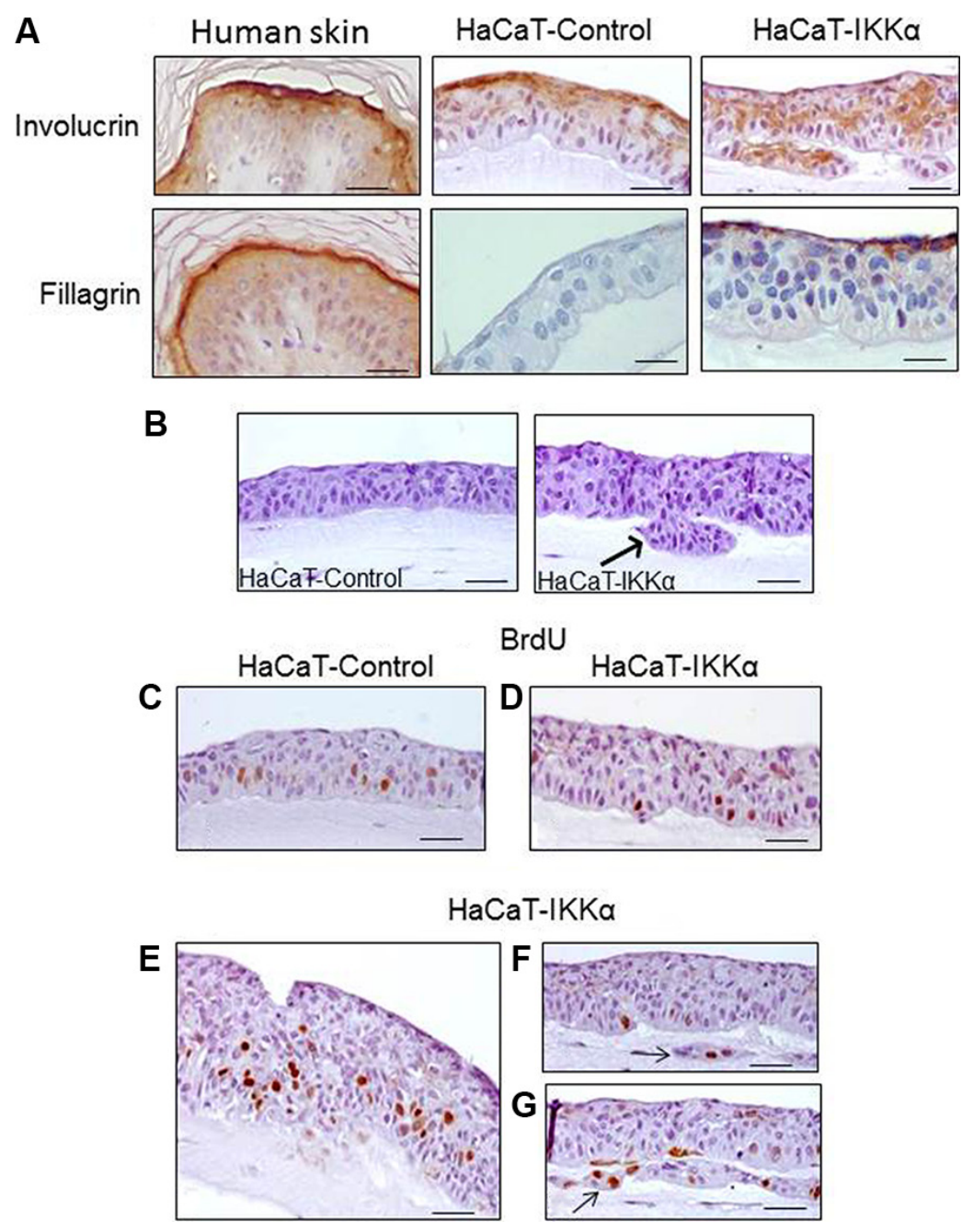

Figure 2: Altered differentiation, increased proliferation and invasion foci in the HaCaT-IKKa skin equivalents. (A) Immunostaining with two markers of epidermal differentiation; involucrin (upper panel) and filaggrin (a marker of upper terminal epidermal differentiation), (lower panel). The expression of these proteins in normal human epidermis as well as in HaCaT Control and HaCaT-IKK $\alpha$ skin equivalents is shown. (B) Invasive foci are observed in the 3D cultures of HaCaT-IKK $\alpha$ keratinocytes (arrow). (C-G) Representative examples of BrdU incorporation. (C) HaCaT-Control skin equivalents: observe the predominance of signal in the basal layer; (D-G) BrdU signal in HaCaT-IKK $\alpha$ skin equivalents. (D) The BrdU staining in areas with light stratification defects in the HaCaT-IKK $\alpha$ skin equivalents is similar to that of HaCaT-Control (C); (E) BrdU incorporation in basal as well as suprabasal layers of keratinocytes is detected in areas where HaCaT-IKK $\alpha$ equivalents exhibit more aberrant stratification; ( $\mathrm{F}-\mathrm{G})$ BrdU positive signal are detected in foci of invasion (arrows). Scale bar: $30 \mu \mathrm{m}(\mathrm{A}) ; 40 \mu \mathrm{m}(\mathrm{C}-\mathrm{G}) ; 50 \mu \mathrm{m}(\mathrm{B})$. 
(Figure 3C); moreover the BrdU incorporation was also significantly higher in HaCaT- IKK $\alpha$ cells- indicating an enhanced proliferation- (Figure 3D). As a possible cause for this increase, we checked the expression of cyclin D1, one of the main cell cycle regulators that is positively regulated by IKK $\alpha$ [15], and found that it was induced in HaCaT-IKK $\alpha$ cells (Figure $3 \mathrm{E}$ ). These results agree with our previous data showing increased expression of cyclin D1 in transgenic mice with exogenous expression of IKK $\alpha$ in the epidermis (K5-IKK $\alpha$ mice) [11].

\section{IKK $\alpha$ augments metalloprotease proteolytic activity of the HaCaT-IKKa skin equivalents and induces the expression of oncogenic proteins in HaCaT keratinocytes}

By the time that the skin equivalents were collected, HaCaT-IKK $\alpha$ 3D cultures could be macroscopically distinguished from the HaCaT-Control skin equivalents by an evident reduction of the dermal compartment, i.e., a reduction in the thickness of the fibrin gel. This observation together with the above mentioned signs of invasiveness (Figure 2B) leaded us to study the proteolytic activity of MMP-2 and MMP-9, two matrix metalloproteases involved in the promotion of cancer cell invasion [16]. Increased proteolytic activity of MMP-9 was found in the HaCaT-IKK $\alpha$ skin equivalents by gelatin zymography, while MMP-2 activity did not change significantly (Figure 4A). This result was also confirmed by western blot analysis, using specific antibodies, which showed increased expression of MMP-9 metalloprotease (Figure 4B). Searching for a possible cause of this increase in MMP-9 levels we analyzed Snail, a positive regulator of MMP-9 expression that promotes cell invasion [17]. We found that Snail expression was induced in the HaCaTIKK $\alpha$ skin equivalents, in comparison to the HaCaTControl skin equivalents (Figure 4B). Another protein that accelerates cell motility and invasion of keratinocytes, is Podoplanin [18], a mucin-type transmembrane glycoprotein that is up-regulated in human squamous cell carcinomas of the skin [19]. The analysis of Podoplanin expression showed that it was highly induced in the HaCaT-IKK $\alpha$ skin equivalents (Figure 4B).

\section{Genetic profiling of HaCaT-Control and HaCaT- IKKa skin equivalents}

To further identified genetic changes induced by IKK $\alpha$ overexpression in 3D cultures of human keratinocytes, we performed expression profiling on HaCaT-Control and HaCaT-IKK $\alpha$ skin equivalents (10 days). Total number of overexpressed and repressed
A
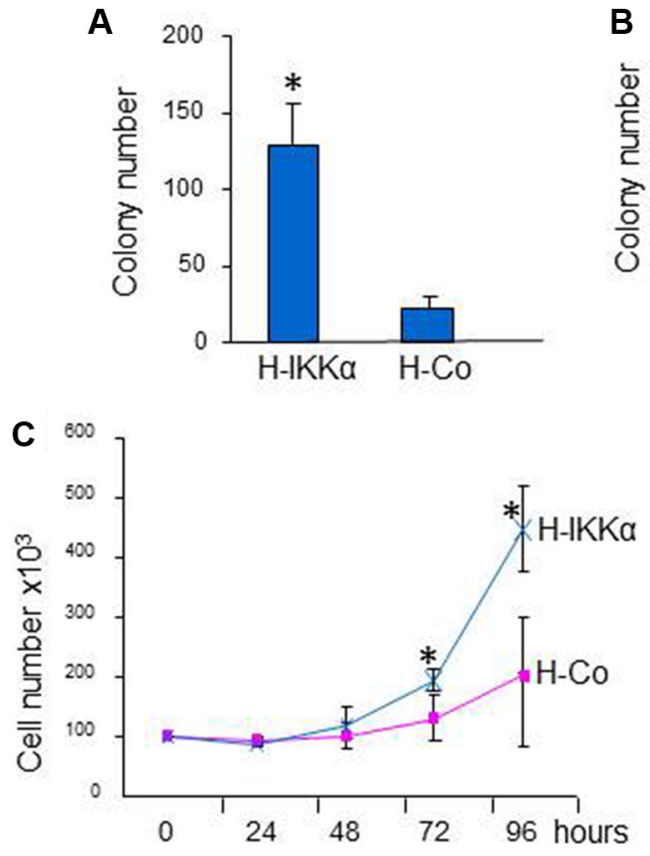

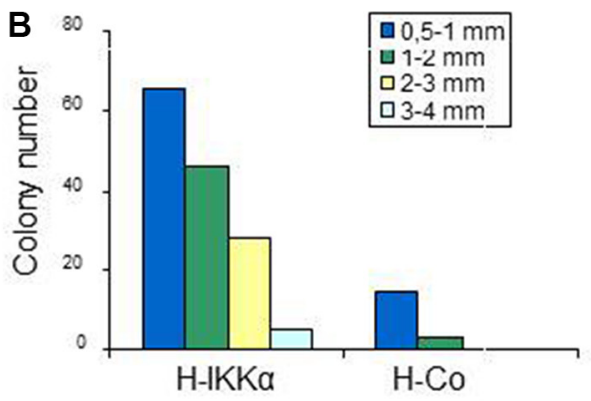

E

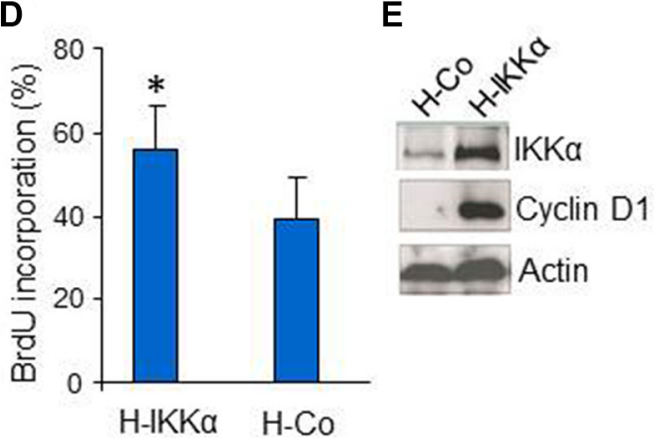

Figure 3: Increased growth in HaCaT-IKKa keratinocytes. (A, B) Clonogenic assay. The mean of three different experiments is shown. (A) Total number of colonies grown 14-days after seeding HaCaT keratinocytes of both genotypes. (B) Representative example of size diameter distribution of colonies in a clonogenic assay. Colony size was measured using a magnifier. Colonies of diameter $>0.5 \mathrm{~mm}$ were counted and classified according to their diameter. (C) Growth curves of HaCaT-IKK $\alpha$ and HaCaT-Control keratinocytes. Three plates of cells were counted at the indicated times. Growth of HaCaT-IKK $\alpha$ cells was significantly higher at 72 and $96 \mathrm{~h}$ post seeding. (D) BrdU incorporation by HaCaT-Control and HaCaT-IKK $\alpha$ cells after $72 \mathrm{~h}$ of culture on coverslides. (E) Western blot showing the increased expression of CyclinD1 in HaCaT-IKK $\alpha$ cells. Student's $T$ test was used for statistical analysis. ${ }^{*} p<0.05$. H-IKK $\alpha=\mathrm{HaCaT}-\mathrm{IKK} \alpha$ cells; $\mathrm{H}-\mathrm{Co}=$ HaCaT-Control cells. 
genes was 122 and 88 respectively. Bioinformatic analysis based in gene function and ontology (Table 1), revealed a striking increase in the expression of genes related to keratinocyte differentiation, epidermis development and cornified envelope, such as $C N F N$; genes encoding small proline-rich proteins (SPRR2C, SPRR3); CDSN; SCEL; KRTDAP; LCE3D; TGM1, etc). There was also an upregulation of genes involved in establishing cell-cell junctions and desmosomes (DSC2; DSG1; CDSN POF1B; $C E A C A M 1$; $L M O 7$; OCLN...). Specially remarkable is the upregulation in $\mathrm{HaCaT}-\mathrm{IKK} \alpha$ skin equivalents of genes involved in the development of various skin disorders, such as pruritus $(K L K 5, K L K 7 ; I L 1 \beta)$; dermatitis $(B M P 6$, TNFaIP6); eczema (VNN3, IL1RL1, SPRR2B, SPRR3), psoriasis (CDSN, KLK, LCN2,IL1 $)$, palmoplantar keratoderma (SLURP1; DSC2; DSG1), and ichthyosis (TGM1; ABCA12; ALOX12B, KLK5). An upregulation of genes implicated in immune response (DPP4, CD24; DEFB1; COLEC12; RFTN1; IL1 $\beta$; RSAD2) was also seen, which is interesting, as in addition to its well known function in epidermal homeostasis, IKK $\alpha$ has been previously related with immunity functions [20, 21]). Moreover, we observed increased expression of genes that are also overexpressed in different types of cancer (SPINK7; BEX2, EDN1, CEACAM; PDPN; EREG; FBN1; CTHRC1; SLC6A14; IL1 $\beta$ etc), among them we found upregulation of genes involved in the development of skin carcinomas (LCN2; TNFRSF19 etc.); head and neck squamous cell carcinomas (CRTC1, CCNA1 (CYCLIN A1); EREG; NEFL; LCE3D), and prostate cancer (PDPN (podoplanin), LCN2). In addition, although the number and function of downregulated genes seemed to be less relevant than those upregulated, however we have identified that some of them also appear downregulated in prostate cancer (DST; VAV3; PLK3HH2; ITG6B; PPMIL). The complete list of differentially expressed genes is shown in Table 2 and Supplementary Table S1. Therefore, these results obtained from the genetic profile analysis of $\mathrm{HaCaT}-\mathrm{IKK} \alpha$ skin equivalents agree with the histological and biochemical analysis presented above, as well as with our previous observations in vitro [12], altogether supporting the increased proliferation, the altered and enhanced terminal differentiation, and the invasive capacity observed in HaCaT-IKK $\alpha$ keratinocytes growing in $3 \mathrm{D}$ cultures. In addition microarrays analysis has also revealed a number of skin diseases and different types of cancer that may be related to the increased expression of IKK $\alpha$.

\section{DISCUSSION}

Our model of $\mathrm{HaCaT}$ skin equivalents developed to study the function of IKK $\alpha$ in the epidermal homeostasis and in skin cancer has demonstrated to be a useful approach for these purposes. Our results show that IKK $\alpha$ promotes the rapid differentiation of keratinocytes in skin equivalents, confirming the fundamental role of IKK $\alpha$ in this process that has been previously reported $[1,3,12]$; moreover, our new model of HaCaT-IKK $\alpha$ skin equivalents has allowed us the sequential study of the epidermal stratification process, showing that keratinocytes overexpressing IKK $\alpha$ exhibit a pathological differentiation, displaying remarkable alterations in tissue stratification and keratinocyte orientation, suggesting that levels of expression of IKK $\alpha$ must be strictly regulated. Enhanced keratinocyte proliferation was also observed in the HaCaT-IKK $\alpha$ skin equivalents, probably due to an effort to counteract the fast differentiation rate of the suprabasal layers. This result is in agreement with the loss of tissue architecture that the epidermis of K5IKK $\alpha$ transgenic mice displayed when it was exposed to proliferative stimulus (as cutaneous TPA treatment) [11]. Loss of epidermal tissue architecture is considered a premalignant signal and it is remarkable that additional signs of premalignancy have been detected in the $\mathrm{HaCaT-IKK} \alpha$ skin equivalents, such as the expression of oncogenic proteins (Podoplanin, Snail, Cyclin D1); the increased expression and proteolytic activity due to MMP-9 increase; and the presence of foci of keratinocyte invasion. These features suggest the predisposition towards
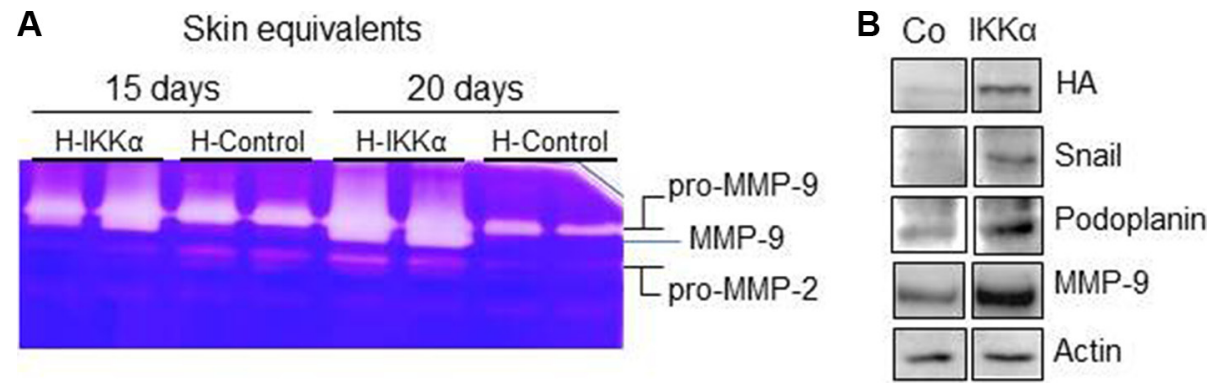

Figure 4: Increased metalloprotease proteolytic activity and increased expression of MMP-9, Snail and Podoplanin in the HaCaT-IKKa skin equivalents. (A) MMP-2 and -MMP-9 activity was evaluated by gelatin zymography, using protein from culture supernatant of HaCaT-Control and HaCaT-IKK $\alpha$ skin equivalents at the indicated days of growth in air-liquid interface. White bands of proteolytic activity were revealed on a Coomassie-Blue stained gelatin gel. (B) Western blot showing the increased expression of Snail, Podoplanin and MMP-9 proteins in the HaCaT-IKK $\alpha$ skin equivalents grown for 12-days in air-liquid interface. Actin was used as a loading control. 
Table 1: Bioinformatic analysis of microarrays based on gene function and ontology

\begin{tabular}{|c|c|c|c|c|c|c|}
\hline \multicolumn{7}{|l|}{ UPREGULATED } \\
\hline Category & Name & $p$-value & $\begin{array}{l}q \text {-value } \\
\text { FDR B\&H }\end{array}$ & $\begin{array}{l}\text { Hit Count in } \\
\text { Query List }\end{array}$ & $\begin{array}{l}\text { Hit Count in } \\
\text { Genome }\end{array}$ & Hit in Query List \\
\hline GO: Biological Process & keratinocyte differentiation & $5.36 \mathrm{E}-13$ & $1.41 \mathrm{E}-09$ & 13 & 138 & $\begin{array}{l}\text { CRCT1,CDSN,EREG,CNFN,ABCA12,S } \\
\text { PRR2B,SPRR2G,SPRR3,SCEL,TGM1,L } \\
\text { CE3D,PRR9,ALOX15B }\end{array}$ \\
\hline GO: Biological Process & epidermis development & $3.72 \mathrm{E}-12$ & 4.88E-09 & 17 & 340 & $\begin{array}{l}\text { CRCT1,CDSN,KLK7,EREG,CNFN,ABC } \\
\text { A12,SPRR2B,SPRR2G,SPRR3,SCEL,T } \\
\text { GM1,LCE3D,KRTDAP,PRR9,TNFRSF1 } \\
\text { 9,KLK5,ALOX15B }\end{array}$ \\
\hline GO: Biological Process & $\mathrm{T}$ cell mediated immunity & $9.44 \mathrm{E}-06$ & $2.75 \mathrm{E}-03$ & 6 & 90 & $\begin{array}{l}\text { DPP4,CEACAM1,RFTN1,RSAD2,P2R } \\
\text { X7,IL1B }\end{array}$ \\
\hline GO: Biological Process & immune response & $2.89 \mathrm{E}-05$ & $5.42 \mathrm{E}-03$ & 22 & 1572 & $\begin{array}{l}\text { DPP4,KLK7,EREG,GBP1,LCN2,EDN1, } \\
\text { CEACAM1,DEFB1,COLEC12,RFTN1,B } \\
\text { MP6,RSAD2,P2RX7,CD24,RORA,IFI44 } \\
\text { L,IL1RL1,KLK5,IL1B,IL36G,MX1,MX2 }\end{array}$ \\
\hline GO: Biological Process & keratinocyte proliferation & $1.32 \mathrm{E}-03$ & $4.18 \mathrm{E}-02$ & 3 & 40 & EREG,SLURP1,TGM1 \\
\hline GO: Cellular Component & cornified envelope & $7.49 \mathrm{E}-14$ & $1.54 \mathrm{E}-11$ & 10 & 48 & $\begin{array}{l}\text { CRCT1,CDSN,CNFN,SPRR2B,SPRR2G, } \\
\text { SPRR3,SCEL,TGM1,LCE3D,PRR9 }\end{array}$ \\
\hline GO: Cellular Component & cell-cell junction & $5.59 \mathrm{E}-08$ & $5.76 \mathrm{E}-06$ & 14 & 418 & $\begin{array}{l}\text { DPP4,CDSN,AOC1,DSC2,DSG1,SH3KB } \\
\text { P1,TENM2,POF1B,CEACAM1,SLC5A1, } \\
\text { TGM1,P2RX7,LMO7,OCLN }\end{array}$ \\
\hline GO: Cellular Component & epidermal lamellar body & $6.11 \mathrm{E}-07$ & 4.19E-05 & 3 & 4 & KLK7,ABCA12,KLK5 \\
\hline GO: Cellular Component & extracellular space & 7.84E-06 & $4.04 \mathrm{E}-04$ & 22 & 1449 & $\begin{array}{l}\text { COL6A3,KLK7,EREG,AOC1,SLURP1, } \\
\text { CEACAM6,ADAMTS5,LCN2,EDN1,CE } \\
\text { ACAM1,DEFB1,BMP6,FBN1,PTPRG,A } \\
\text { 2ML1,CTHRC1,IL1RL1,KLK5,TNFAIP } \\
\text { 6,IL1B,IL36G,DKK2 }\end{array}$ \\
\hline GO: Cellular Component & desmosome & $1.10 \mathrm{E}-05$ & $4.52 \mathrm{E}-04$ & 4 & 26 & CDSN,DSC2,DSG1,POF1B \\
\hline Human Phenotype & Palmoplantar keratoderma & $1.35 \mathrm{E}-08$ & $5.06 \mathrm{E}-06$ & 7 & 60 & $\begin{array}{l}\text { DSC2,DSG1,ABCA12,SLURP1,TGM1,C } \\
\text { YP4F22,ALOX12B }\end{array}$ \\
\hline Human Phenotype & Congenital ichthyosiform erythroderma & $2.74 \mathrm{E}-05$ & $5.13 \mathrm{E}-03$ & 3 & 12 & ABCA12,TGM1,ALOX12B \\
\hline Human Phenotype & $\begin{array}{l}\text { Congenital nonbullous ichthyosiform } \\
\text { erythroderma }\end{array}$ & $4.50 \mathrm{E}-05$ & $5.62 \mathrm{E}-03$ & 3 & 14 & TGM1,CYP4F22,ALOX12B \\
\hline Pubmed & $\begin{array}{l}\text { Association of psoriasis to PGLYRP and } \\
\text { SPRR genes at PSORS4 locus on } 1 \mathrm{q} \text { shows } \\
\text { heterogeneity between Finnish, Swedish and } \\
\text { Irish families. }\end{array}$ & $6.07 \mathrm{E}-06$ & $1.63 \mathrm{E}-03$ & 3 & 12 & SPRR2B,SPRR2G,SPRR3 \\
\hline Gene Family & Interleukins and interleukin receptors & $1.49 \mathrm{E}-03$ & $1.19 \mathrm{E}-02$ & 3 & 71 & IL1RL1,IL1B,IL36G \\
\hline Coexpression & $\begin{array}{l}\text { Cluster c: genes identifying an intrinsic } \\
\text { group in head and neck squamous cell } \\
\text { carcinoma (HNSCC). }\end{array}$ & $9.51 \mathrm{E}-27$ & $5.81 \mathrm{E}-23$ & 20 & 112 & $\begin{array}{l}\text { CRCT1,CDSN,KLK7,EREG,CALB1,CW } \\
\text { H43,DSG1,ABCA12,SPRR2G,SLC6A15, } \\
\text { NEFL,LCE3D,KRTDAP,CCNA1,PRR9,IL } \\
\text { 1RL1,KLK5,IL36G,ALOX12B,SLC6A14 }\end{array}$ \\
\hline Coexpression & $\begin{array}{l}\text { Cluster e: genes identifying an intrinsic } \\
\text { group in head and neck squamous cell } \\
\text { carcinoma (HNSCC). }\end{array}$ & $2.68 \mathrm{E}-13$ & $1.64 \mathrm{E}-10$ & 11 & 89 & $\begin{array}{l}\text { CEACAM5,SPRR2C,CEACAM7,SLUR } \\
\text { P1,SCEL,POF1B,TMEM45B,SPINK7,A } \\
\text { 2ML1,TMPRSS11D,ALOX15B }\end{array}$ \\
\hline Coexpression & Human HeadandNeck_Toruner04_20genes & $2.78 \mathrm{E}-07$ & $3.54 \mathrm{E}-05$ & 4 & 13 & DSG1,SPRR3,CEACAM6,SCEL \\
\hline Coexpression & $\begin{array}{l}\text { Genes up-regulated in mice with skin } \\
\text { specific double knockout of both RB1 and } \\
\text { TP5 } 3 \text { by Cre-lox. }\end{array}$ & 3.39E-06 & $2.54 \mathrm{E}-04$ & 13 & 601 & $\begin{array}{l}\text { EREG,TMEM45A,SH3KBP1,SLURP1, } \\
\text { GBP1,CEACAM1,RSAD2,PTPRG,SUL } \\
\text { T2B1,KRTDAP,IL1RL1,TNFAIP6,IL36G }\end{array}$ \\
\hline Coexpression & $\begin{array}{l}\text { Genes down-regulated in epithelial prostate } \\
\text { cancer cell lines over-expressing an } \\
\text { oncogenic form of KRAS gene. }\end{array}$ & 4.09E-06 & $2.63 \mathrm{E}-04$ & 7 & 143 & $\begin{array}{l}\text { CWH43,SPRR3,SCEL,LCN2,EDN1,TG } \\
\text { M1,SLC6A14 }\end{array}$ \\
\hline Coexpression & $\begin{array}{l}\text { Genes up-regulated in epidermis after to } \\
\text { UVB irradiation. }\end{array}$ & 7.71E-06 & 4.62E-04 & 9 & 293 & $\begin{array}{l}\text { RHCG,DSC2,SPRR2B,TGM1,DHRS9,C } \\
\text { D24,UPP1,CYB5R2,MX1 }\end{array}$ \\
\hline Coexpression & $\begin{array}{l}\text { Genes up-regulated in hepatocellular } \\
\text { carcinoma (HCC) from MYC and E2F1 } \\
\text { double transgenic mice. }\end{array}$ & $1.23 \mathrm{E}-04$ & $3.87 \mathrm{E}-03$ & 4 & 56 & TMEM176B,IFI44,LCN2,DEFB1 \\
\hline Coexpression & $\begin{array}{l}\text { Genes up-regulated upon knockdown of } \\
\text { PTEN by RNAi. }\end{array}$ & $2.26 \mathrm{E}-04$ & $6.41 \mathrm{E}-03$ & 6 & 189 & $\begin{array}{l}\text { SCEL,EDN1,DEFB1,RSAD2,CYB5R2 } \\
\text {,MX2 }\end{array}$ \\
\hline Coexpression & $\begin{array}{l}\text { Genes up-regulated in RWPE-1 cells } \\
\text { (prostate cancer) upon expression of } \\
\text { constitutively active form of STAT3. }\end{array}$ & 2.29E-04 & $6.46 \mathrm{E}-03$ & 5 & 121 & CALB1,PDPN,NEFL,NSG1,MX1 \\
\hline Coexpression & $\begin{array}{l}\text { Up-regulated genes in the cancer gene } \\
\text { signature, representing a gene signature of } \\
\text { cellular transformation. }\end{array}$ & 8.37E-04 & $1.58 \mathrm{E}-02$ & 6 & 242 & $\begin{array}{l}\text { EREG,SLC2A3,SLC39A8,UPP1,IL1B, } \\
\text { CYB5R2 }\end{array}$ \\
\hline Disease & Dermatologic disorders & $1.43 \mathrm{E}-08$ & $2.23 \mathrm{E}-05$ & 14 & 371 & $\begin{array}{l}\text { DPP4,CDSN,KLK7,DSC2,DSG1,SPRR3 } \\
\text {,SLURP1,LCN2,POF1B,EDN1,TGM1,R } \\
\text { ORA,TNFAIP6,IL1B }\end{array}$ \\
\hline
\end{tabular}




\begin{tabular}{|c|c|c|c|c|c|c|}
\hline Disease & $\begin{array}{l}\text { Congenital Nonbullous Ichthyosiform } \\
\text { Erythroderma }\end{array}$ & $1.94 \mathrm{E}-06$ & $1.01 \mathrm{E}-03$ & 4 & 17 & ABCA12,TGM1,CYP4F22,ALOX12B \\
\hline Disease & Eczema & $1.10 \mathrm{E}-05$ & $3.43 \mathrm{E}-03$ & 11 & 396 & $\begin{array}{l}\text { DPP4,COL6A3,KLK7,SPRR2B,SPRR3,V } \\
\text { NN3,DEFB1,TGM1,IL1RL1,KLK5,IL1B }\end{array}$ \\
\hline Disease & Squamous cell carcinoma & $1.39 \mathrm{E}-05$ & $3.62 \mathrm{E}-03$ & 23 & 1608 & $\begin{array}{l}\text { EREG,CEACAM5,DSC2,DSG1,SPRR3, } \\
\text { SH3KBP1,SYTL2,CEACAM7,ODC1,LC } \\
\text { N2,EDN1,SLC2A3,PDPN,DEFB1,TGM1 } \\
\text {,SPINK7,C15orf48,CCNA1,CTHRC1,KL } \\
\text { K5,IL1B,BEX2,ALOX12B }\end{array}$ \\
\hline Disease & Pruritus & $1.65 \mathrm{E}-05$ & $3.68 \mathrm{E}-03$ & 5 & 58 & CDSN,KLK7,EDN1,KLK5,IL1B \\
\hline Disease & Hyperkeratosis & $2.48 \mathrm{E}-05$ & $4.83 \mathrm{E}-03$ & 5 & 63 & CDSN,DSG1,ABCA12,TGM1,IL1B \\
\hline Disease & Harlequin Fetus & $3.43 \mathrm{E}-05$ & $5.35 \mathrm{E}-03$ & 3 & 12 & ABCA12,TGM1,KLK5 \\
\hline Disease & Skin lesion & 4.14E-05 & $5.87 \mathrm{E}-03$ & 5 & 70 & DSG1,EDN1,CEACAM1,DEFB1,IL1B \\
\hline Disease & Psoriasis & $1.68 \mathrm{E}-04$ & $1.54 \mathrm{E}-02$ & 12 & 629 & $\begin{array}{l}\text { CDSN,KLK7,VNN3,LCN2,EDN1,DEF } \\
\text { B1,TGM1,LCE3D,PRR9,KLK5,IL1B,A } \\
\text { LOX15B }\end{array}$ \\
\hline Disease & Pancreatic carcinoma & $2.23 \mathrm{E}-04$ & $1.73 \mathrm{E}-02$ & 21 & 1666 & $\begin{array}{l}\text { COL6A3,KLK7,CEACAM5,ERN1,CEA } \\
\text { CAM7,CEACAM6,ODC1,LCN2,CEAC } \\
\text { AM1,KRT23,PDPN,CCDC88A,PTPRG, } \\
\text { P2RX7,NAV3,CD24,CTHRC1,OCLN,IL } \\
\text { 1B,FKBP5,DKK2 }\end{array}$ \\
\hline Disease & Dermatitis, Allergic Contact & 2.72E-04 & $2.02 \mathrm{E}-02$ & 5 & 104 & SLC2A3,BMP6,UPP1,TNFAIP6,IL1B \\
\hline Disease & Precancerous Conditions & $5.32 \mathrm{E}-04$ & $2.86 \mathrm{E}-02$ & 9 & 423 & $\begin{array}{l}\text { COL6A3,CEACAM5,SYTL2,CEACAM7, } \\
\text { ODC1,LCN2,CD24,IL1B,ALOX15B }\end{array}$ \\
\hline Disease & Thyroid carcinoma & 7.18E-04 & $3.49 \mathrm{E}-02$ & 11 & 635 & $\begin{array}{l}\text { DPP4,CDSN,LCN2,EDN1,CEACAM1,P } \\
\text { DPN,DEFB1,FBN1,P2RX7,NSG1,IL1B }\end{array}$ \\
\hline Disease & Prostatic Hyperplasia & $8.56 \mathrm{E}-04$ & $3.60 \mathrm{E}-02$ & 3 & 34 & IFI44,EDN1,ALOX15B \\
\hline Disease & Ichthyosis linearis circumflexa & $1.19 \mathrm{E}-03$ & $4.84 \mathrm{E}-02$ & 3 & 38 & KLK7,DSG1,KLK5 \\
\hline Disease & Skin Neoplasms & $1.23 \mathrm{E}-03$ & $4.84 \mathrm{E}-02$ & 6 & 216 & $\begin{array}{l}\text { DPP4,DSC2,ODC1,LCN2,TNFRSF19, } \\
\text { IL1B }\end{array}$ \\
\hline Disease & Esophageal carcinoma & $1.28 \mathrm{E}-03$ & 4.84E-02 & 10 & 578 & $\begin{array}{l}\text { CEACAM5,DSC2,SPRR3,ODC1,LCN2 } \\
\text {,PDPN,BMP6,SPINK7,IL1B,ALOX15B }\end{array}$ \\
\hline \multicolumn{7}{|l|}{ DOWNREGULATED } \\
\hline Category & Name & $p$-value & $q$-value FDR B\&H & $\begin{array}{l}\text { Hit Count in } \\
\text { Query List }\end{array}$ & $\begin{array}{l}\text { Hit Count in } \\
\text { Genome }\end{array}$ & Hit in Query List \\
\hline GO: Molecular Function & receptor binding & $1.43 \mathrm{E}-05$ & $5.62 \mathrm{E}-03$ & 18 & 1601 & $\begin{array}{l}\text { REEP1,NTRK2,CXCL14,CAT,EDIL3,IT } \\
\text { GB6,LYPD1,DST,SEMA6D,LRP4,NCO } \\
\text { A7,CCL2,PLAT,VAV3,MMP13,FYB,IL3 } \\
\text { 3,EPHA4 }\end{array}$ \\
\hline GO: Biological Process & response to wounding & $3.52 \mathrm{E}-07$ & $8.69 \mathrm{E}-04$ & 16 & 967 & $\begin{array}{l}\text { SOX2,CFH,TNC,TFPI2,DST,CLU,CD36, } \\
\text { SCGB1A1,PLA2G2A,CCL2,PLAT,VAV3 } \\
\text {,DUSP10,MMP12,IL33,EPHA4 }\end{array}$ \\
\hline GO: Biological Process & response to growth factor & $5.82 \mathrm{E}-06$ & $3.07 \mathrm{E}-03$ & 12 & 671 & $\begin{array}{l}\text { SOX2,TNC,NTRK2,MECOM,CAT,RNF } \\
\text { 165,CLU,SCGB1A1,LRP4,CCL2,EEF2 } \\
\text { K,FGFR2 }\end{array}$ \\
\hline GO: Biological Process & MAPK cascade & $1.39 \mathrm{E}-04$ & $1.43 \mathrm{E}-02$ & 12 & 928 & $\begin{array}{l}\text { SOX2,NTRK2,MECOM,CD36,MID1,PP } \\
\text { M1L,PLA2G2A,CCL2,DUSP10,FGFR2, } \\
\text { CTSH,EPHA4 }\end{array}$ \\
\hline GO: Biological Process & aging & $9.75 \mathrm{E}-04$ & $3.58 \mathrm{E}-02$ & 6 & 308 & NTRK2,CAT,RNF165,CLU,UCP2,CCL2 \\
\hline GO: Cellular Component & extracellular space & $1.14 \mathrm{E}-07$ & $3.10 \mathrm{E}-05$ & 20 & 1449 & $\begin{array}{l}\text { CFH,PCSK5,SEPP1,TCN1,PLXDC1,TN } \\
\text { C,OLFM4,CXCL14,CAT,CLU,CD36,SC } \\
\text { GB1A1,APOL4,PLA2G2A,CCL2,PLAT, } \\
\text { MMP13,CTSH,IL33,GABBR1 }\end{array}$ \\
\hline GO: Cellular Component & cytoplasmic, membrane-bounded vesicle & $2.66 \mathrm{E}-07$ & $3.10 \mathrm{E}-05$ & 18 & 1237 & $\begin{array}{l}\text { PCSK5,SEPP1,HLA-DRA,OLFM4,CEMI } \\
\text { P,DST,CLU,CD36,SCGB1A1,AP3M2,PL } \\
\text { A2G2A,CCL2,PLAT,FGFR2,CTSH,PCD } \\
\text { H7,IL33,GABBR1 }\end{array}$ \\
\hline GO: Cellular Component & secretory vesicle & $3.21 \mathrm{E}-06$ & $1.28 \mathrm{E}-04$ & 11 & 535 & $\begin{array}{l}\text { PCSK5,SEPP1,OLFM4,CLU,CD36,SC } \\
\text { GB1A1,PLA2G2A,PLAT,CTSH,PCDH7 } \\
\text {,GABBR1 }\end{array}$ \\
\hline Coexpression & $\begin{array}{l}\text { Genes down-regulated in prostate cancer } \\
\text { samples. }\end{array}$ & $1.45 \mathrm{E}-11$ & $8.28 \mathrm{E}-08$ & 15 & 480 & $\begin{array}{l}\text { KRT15,KRT19,MECOM,ITGB6,FADS1 } \\
\text {,DST,SEMA6D,CLU,SCGB1A1,EEF2K } \\
\text {,VAV3,FGFR2,PLEKHH2,PCDH7,IL33 }\end{array}$ \\
\hline Coexpression & $\begin{array}{l}\text { Selected genes up-regulated in prostate } \\
\text { tumors developed by transgenic mice } \\
\text { overexpressing VAV3 in prostate epithelium. }\end{array}$ & $3.21 \mathrm{E}-07$ & $1.04 \mathrm{E}-04$ & 6 & 89 & CFH,TNC,ITGB6,CD36,PLAT,EPHA4 \\
\hline Coexpression & $\begin{array}{l}\text { Genes with promoters occupied by SMAD2 } \\
\text { or SMAD3 in HaCaT cells (keratinocyte) } \\
\text { according to a ChIP-chip analysis. }\end{array}$ & $3.95 \mathrm{E}-05$ & 3.37E-03 & 11 & 823 & $\begin{array}{l}\text { KRT15,KRT19,TNC,TFPI2,EDIL3,LYPD } \\
\text { 1,FADS1,DST,CLU,CCL2,DUSP10 }\end{array}$ \\
\hline Coexpression & $\begin{array}{l}\text { Genes down-regulated in metastatic tumors } \\
\text { from the whole panel of patients with } \\
\text { prostate cancer. }\end{array}$ & $4.18 \mathrm{E}-05$ & $3.37 \mathrm{E}-03$ & 7 & 305 & $\begin{array}{l}\text { SOX2,THSD4,KRT15,CHRM3,PPM1L,F } \\
\text { GFR2,PCDH7 }\end{array}$ \\
\hline
\end{tabular}




\begin{tabular}{|c|c|c|c|c|c|c|}
\hline Coexpression & $\begin{array}{l}\text { Integrin, VEGF, Wnt and TGFbeta signaling } \\
\text { pathway genes down-regulated in PC-3 cells } \\
\text { (prostate cancer) after knockdown of PDEF } \\
\text { by RNAi. }\end{array}$ & 2.34E-04 & $1.05 \mathrm{E}-02$ & 3 & 39 & KRT19,PIK3R3,ITGB6 \\
\hline Disease & Malignant tumor of colon & $1.07 \mathrm{E}-10$ & $1.84 \mathrm{E}-07$ & 27 & 1714 & $\begin{array}{l}\text { SOX2,CFH,SEPP1,KRT19,UBD,TNC,TF } \\
\text { PI2,NTRK2,OLFM4,SLFN12,MECOM,C } \\
\text { AT,EDIL3,CHRM3,ITGB6,CEMIP,LOC1 } \\
\text { 01930123,CLU,CD36,UCP2,PLA2G2A,C } \\
\text { CL2,PLAT,EEF2K,FGFR2,MMP13,XPR1 }\end{array}$ \\
\hline Disease & Malignant neoplasm of pancreas & $3.16 \mathrm{E}-06$ & $6.83 \mathrm{E}-04$ & 20 & 1619 & $\begin{array}{l}\text { SOX2,SEPP1,KRT19,TNC,TFPI2,NTRK } \\
\text { 2,OLFM4,CXCL14,BCKDHB,CLDN8,L } \\
\text { OC101930123,CLU,CCL2,EEF2K,FGFR } \\
\text { 2,MMP12,IL33,GABBR1,EPHA4,XPR1 }\end{array}$ \\
\hline Disease & Atrophic condition of skin & $7.78 \mathrm{E}-06$ & $1.04 \mathrm{E}-03$ & 6 & 118 & CFH,KRT19,SLFN12,CLU,CCL2,FGFR2 \\
\hline Disease & Malignant neoplasm of skin & $2.52 \mathrm{E}-04$ & 7.27E-03 & 6 & 220 & KRT19,CAT,PLAT,FGFR2,MMP12,IL33 \\
\hline Disease & Squamous cell carcinoma & $4.35 \mathrm{E}-05$ & $2.90 \mathrm{E}-03$ & 18 & 1608 & $\begin{array}{l}\text { SOX2,KRT19,TNC,TFPI2,MECOM,CXC } \\
\text { L14,CAT,ITGB6,DST,CLU,CD36,CCL2,P } \\
\text { LAT,VAV3,FGFR2,MMP12,MMP13,IL33 }\end{array}$ \\
\hline
\end{tabular}

malignant transformation of keratinocytes overexpressing IKK $\alpha$, and agree with our previous data showing that K5IKK $\alpha$ transgenic mice presented an enhanced malignant potential for developing skin tumors [11]; they are also in accordance with our previous results showing the more aggressive phenotype of skin carcinomas arisen in immunodeficient mice injected with PDVC57 tumoral keratinocytes overexpressing IKK $\alpha$ [12].

Some of the proteins regulated by IKK $\alpha$ in the HaCaT-IKK $\alpha$ skin equivalents have been previously shown to be regulated by IKK $\alpha$ in different contexts, reinforcing the validity of our model. Among them it was reported that IKK $\alpha$ induced cyclin D1 in response to mitogens and DNA synthesis [15]. Here we show that the expression of Cyclin D1 is increased in HaCaT-IKK $\alpha$ keratinocytes that also display increased proliferation. Moreover, we detected augmented levels of Cyclin D1 in the skin of K5-IKK $\alpha$ mice that presented enhanced proliferation as well [11]. Induction of Snail by IKK $\alpha$ has been previously observed in pancreatic cancer cells where it was proposed that Snail was promoting EMT [22]; the induction of MMP-9 by IKK $\alpha$ has also been described in activated human leukocytes [23]. In addition, we have just reported that increased levels of IKK $\alpha$ only in the cytoplasm of both, human $\mathrm{HaCaT}$ keratinocytes and keratinocytes of the basal layer of transgenic mice, induce the expression of MMP-9 [24]. In all these cases IKK $\alpha$ has been proposed to enhance the malignancy of the different types of cells where it was expressed. Actually our recent results show the fast development of more aggressive skin tumors in chemical skin carcinogenesis performed in transgenic mice that overexpress IKK $\alpha$ only in the nucleus or in the cytoplasm of keratinocytes [24].

Data obtained in the analysis of the microarrays of HaCaT-Control and HaCat-IKK $\alpha$ skin equivalents showed upregulation of genes implicated in differentiation/ keratinization, and epidermal barrier formation. These results are in agreement with our experimental studies presented above, indicating the enhanced capacity of terminal differentiation of HaCaT-IKK $\alpha$ keratinocytes (Figure 2). They also agree with our previous observations in vitro showing the accelerated and increased ability of terminal differentiation in monolayer cultures of keratinocytes overexpressing IKK $\alpha$ [12]. They are in agreement as well with data reported by other groups that describe the fundamental role of IKK $\alpha$ in epidermal IKK $\alpha$ morphogenesis and epidermal barrier formation [1-4]. In adition, our expression profiling studies in keratinocytes overexpressing IKK $\alpha$ show opposite results to those obtained in genetic profiling studies of IKK $\alpha$ null keratinocytes, which showed the down-regulation of genes involved in keratinocyte terminal differentiation and epidermal barrier formation [1]. Other differences found between skin equivalents of both genotypes in our microarrays point to the upregulation in the HaCaTIKK $\alpha$ equivalents of genes related to proliferation (such as Cyclin A1); proteolysis (i.e. proteinases of the kallikrein family); and genes implicated in invasiveness (such as podoplanin) (Figure 4 and Tables 1, 2, Supplementary Table S1). Thus, these results could support both the increased proliferation and invasive capacity found above in the HaCaT-IKKa 3D cultures (Figures 2, 3) and could explain the degradation of fibrin gels observed in the HaCaT-IKK $\alpha$ skin equivalents. We have also found changes in the genetic expression profile of HaCaTIKK $\alpha$ skin equivalents of genes implicated in skin cancer development, but, in addition, changes in genes involved in the development and progression of other types of cancer, such as head and neck cancer and prostate cancer has been also established. Remarkably overexpression of IKK $\alpha$ in prostate cancer has been previously found to correlate with poor prognosis [25] and some studies have found a relationship between IKK $\alpha$ activation and head and neck cancer progression [26, 27].

It is interesting that many of the changes in gene expression found in HaCaT-IKK $\alpha$ skin equivalents are 
Table 2: Genes differentially expressed in the HaCat-IKKa skin equivalents (for a complete list, see Supplementary inf, Table 1

\begin{tabular}{|c|c|c|c|c|c|c|c|c|c|}
\hline Probe ID & Gene Symbol & Gene Title & $\begin{array}{l}\text { FoldChange } \\
(\log 2)\end{array}$ & p.value & Probe ID & Gene Symbol & Gene Title & $\begin{array}{l}\text { FoldChange } \\
(\log 2)\end{array}$ & p.value \\
\hline 223720 at & SPINK7 & $\begin{array}{l}\text { serine peptidase inhibitor, Kazal } \\
\text { type } 7 \text { (putative) }\end{array}$ & 2.37 & 0.0017 & 1569948_at & BC047651 & $\begin{array}{l}\text { Homo sapiens cDNA clone } \\
\text { IMAGE: } 5275301 .\end{array}$ & -2.84 & $6.00 \mathrm{E}-04$ \\
\hline 220620_at & CRCT1 & cysteine-rich C-terminal 1 & 2.24 & $\begin{array}{l}2.00 \mathrm{E}- \\
04\end{array}$ & 205413_at & MPPED2 & $\begin{array}{l}\text { metallophosphoesterase } \\
\text { domain containing } 2\end{array}$ & -2.1 & $2.00 \mathrm{E}-04$ \\
\hline 205767_at & EREG & epiregulin & 2.16 & 0.0047 & 214598_at & CLDN8 & claudin 8 & -2.03 & 0.0017 \\
\hline 224329_s_at & CNFN & cornifelin & 2.01 & 0.0015 & 212768_s_at & OLFM4 & olfactomedin 4 & -1.92 & 0.0015 \\
\hline 224328_s_at & LCE3D & late cornified envelope 3D & 1.94 & 0.0015 & 209821_at & IL33 & interleukin 33 & -1.91 & 0.0045 \\
\hline 215465_at & ABCA 12 & $\begin{array}{l}\text { ATP-binding cassette, sub-family A } \\
\text { (ABC1), member } 12\end{array}$ & 1.77 & 0.0024 & 201427_s_at & SEPP1 & selenoprotein $\mathrm{P}$, plasma, 1 & -1.9 & 0.0044 \\
\hline 204439_at & IFI44L & interferon-induced protein 44-like & 1.69 & 0.0045 & 228038_at & SOX2 & $\begin{array}{l}\text { SRY (sex determining region } \\
\text { Y)-box } 2\end{array}$ & -1.88 & 0.0054 \\
\hline 219554_at & RHCG & $\mathrm{Rh}$ family, $\mathrm{C}$ glycoprotein & 1.68 & 0.0024 & 203649_s_at & PLA2G2A & $\begin{array}{l}\text { phospholipase A2, group IIA } \\
\text { (platelets, synovial fluid) }\end{array}$ & -1.86 & $6.00 \mathrm{E}-04$ \\
\hline 211657_at & CEACAM6 & $\begin{array}{l}\text { carcinoembryonic antigen-related } \\
\text { cell adhesion molecule } 6 \text { (non- } \\
\text { specific cross reacting antigen) }\end{array}$ & 1.67 & 0.0015 & 221796_at & NTRK2 & $\begin{array}{l}\text { neurotrophic tyrosine kinase, } \\
\text { receptor, type } 2\end{array}$ & -1.84 & 0.0015 \\
\hline 1564307_a_at & A2ML1 & alpha-2-macroglobulin-like 1 & 1.66 & 0.0118 & 221795 at & NTRK2 & $\begin{array}{l}\text { neurotrophic tyrosine kinase, } \\
\text { receptor, type } 2\end{array}$ & -1.81 & 0.0079 \\
\hline 1554921_a_at & SCEL & sciellin & 1.63 & 0.0015 & 222484_s_at & CXCL14 & $\begin{array}{l}\text { chemokine }(\mathrm{C}-\mathrm{X}-\mathrm{C} \text { motif }) \\
\text { ligand } 14\end{array}$ & -1.6 & 0.0185 \\
\hline 205626_s_at & CALB1 & calbindin $1,28 \mathrm{kDa}$ & 1.62 & 0.0051 & 204580_at & MMP12 & $\begin{array}{l}\text { matrix metallopeptidase } 12 \\
\text { (macrophage elastase) }\end{array}$ & -1.57 & 0.0255 \\
\hline 220664_at & SPRR2C & $\begin{array}{l}\text { small proline-rich protein } 2 \mathrm{C} \\
\text { (pseudogene) }\end{array}$ & 1.61 & 0.0032 & 227266_s_at & FYB & FYN binding protein & -1.57 & 0.0024 \\
\hline 236429_at & ZNF83 & zinc finger protein 83 & 1.6 & 0.0015 & 218002_s_at & CXCL14 & $\begin{array}{l}\text { chemokine (C-X-C motif) } \\
\text { ligand } 14\end{array}$ & -1.54 & 0.015 \\
\hline 218990_s_at & SPRR3 & small proline-rich protein 3 & 1.59 & 0.0034 & 1559633_a_at & CHRM3 & $\begin{array}{ll}\text { cholinergic } & \text { receptor, } \\
\text { muscarinic } 3 & \end{array}$ & -1.42 & 0.0026 \\
\hline 206193_s_at & CDSN & corneodesmosin & 1.57 & 0.0143 & 211795_s_at & FYB & FYN binding protein & -1.31 & 0.0061 \\
\hline 212531_at & LCN2 & lipocalin 2 & 1.55 & 0.0015 & 225123_at & SESN3 & sestrin 3 & -1.31 & 0.0048 \\
\hline 219795_at & SLC6A14 & $\begin{array}{l}\text { solute carrier family } 6 \text { (amino acid } \\
\text { transporter), member } 14\end{array}$ & 1.54 & 0.0127 & 228640_at & PCDH7 & protocadherin 7 & -1.31 & 0.0135 \\
\hline 232056_at & SCEL & sciellin & 1.53 & 0.0015 & 228766_at & $\mathrm{CD} 36$ & $\begin{array}{l}\text { CD36 molecule } \\
\text { (thrombospondin receptor) }\end{array}$ & -1.29 & 0.0045 \\
\hline 206884_s_at & SCEL & sciellin & 1.52 & 0.0015 & 226420_at & MECOM & $\begin{array}{l}\text { MDS1 and EVI1 complex } \\
\text { locus }\end{array}$ & -1.27 & 0.0055 \\
\hline 223484_at & C15orf48 & $\begin{array}{l}\text { chromosome } 15 \text { open reading frame } \\
48\end{array}$ & 1.46 & 0.0071 & 204364_s_at & REEP1 & receptor accessory protein 1 & -1.25 & 0.0068 \\
\hline 205625_s_at & CALB1 & calbindin $1,28 \mathrm{kDa}$ & 1.41 & 0.0045 & 205890_s_at & GABBR1/// UBD & $\begin{array}{l}\text { gamma-aminobutyric acid } \\
\text { (GABA) B receptor, } 1 / / / \\
\text { ubiquitin D }\end{array}$ & -1.21 & 0.0073 \\
\hline 223082_at & SH3KBP1 & $\begin{array}{l}\text { SH3-domain kinase binding protein } \\
1\end{array}$ & 1.4 & 0.0032 & 243546_at & - & - & -1.2 & 0.0079 \\
\hline 1554168_a_at & SH3KBP1 & $\begin{array}{l}\text { SH3-domain kinase binding protein } \\
1\end{array}$ & 1.39 & 0.0015 & 201860_s_at & PLAT & plasminogen activator, tissue & -1.19 & 0.0025 \\
\hline 203234_at & UPP1 & uridine phosphorylase 1 & 1.38 & 0.0091 & 1553705_a_at & CHRM3 & $\begin{array}{ll}\text { cholinergic } & \text { receptor, } \\
\text { muscarinic } 3 & \end{array}$ & -1.18 & 0.0083 \\
\hline 206176_at & BMP6 & bone morphogenetic protein 6 & 1.37 & 0.0065 & 205725_at & SCGB1A1 & $\begin{array}{l}\text { secretoglobin, family } 1 \mathrm{~A}, \\
\text { member } 1 \text { (uteroglobin) }\end{array}$ & -1.16 & 0.0249 \\
\hline 237732_at & PRR9 & proline rich 9 & 1.37 & 0.0073 & 218806_s_at & VAV3 & $\begin{array}{l}\text { vav } 3 \text { guanine nucleotide } \\
\text { exchange factor }\end{array}$ & -1.16 & 0.0034 \\
\hline 203757_s_at & CEACAM6 & $\begin{array}{l}\text { carcinoembryonic antigen-related } \\
\text { cell adhesion molecule } 6 \text { (non- } \\
\text { specific cross reacting antigen) }\end{array}$ & 1.36 & 0.0024 & 205959_at & MMP13 & $\begin{array}{l}\text { matrix metallopeptidase } 13 \\
\text { (collagenase } 3 \text { ) }\end{array}$ & -1.15 & 0.0151 \\
\hline 235438_at & - & - & 1.36 & 0.0233 & 215692_s_at & MPPED2 & $\begin{array}{l}\text { metallophosphoesterase } \\
\text { domain containing } 2\end{array}$ & -1.15 & 0.0055 \\
\hline 206628_at & SLC5A1 & $\begin{array}{l}\text { solute carrier family } 5 \text { (sodium/ } \\
\text { glucose cotransporter), member } 1\end{array}$ & 1.32 & 0.0024 & 201650_at & KRT19 & keratin 19 & -1.14 & 0.0032 \\
\hline 201884_at & CEACAM5 & $\begin{array}{l}\text { carcinoembryonic antigen-related } \\
\text { cell adhesion molecule } 5\end{array}$ & 1.31 & 0.0036 & 242476_at & - & - & -1.14 & 0.0032 \\
\hline 207381_at & ALOX12B & $\begin{array}{l}\text { arachidonate 12-lipoxygenase, } 12 \mathrm{R} \\
\text { type }\end{array}$ & 1.31 & 0.0034 & 208228_s_at & FGFR2 & $\begin{array}{l}\text { fibroblast growth factor } \\
\text { receptor 2 }\end{array}$ & -1.13 & 0.0058 \\
\hline 224009_x_at & DHRS9 & $\begin{array}{l}\text { dehydrogenase/reductase } \\
\text { family) member } 9\end{array}$ & 1.3 & 0.0028 & 221884_at & MECOM & $\begin{array}{l}\text { MDS1 and EVI1 complex } \\
\text { locus }\end{array}$ & -1.13 & 0.0125 \\
\hline
\end{tabular}




\begin{tabular}{|c|c|c|c|c|c|c|c|c|c|}
\hline 235368_at & ADAMTS5 & $\begin{array}{l}\text { ADAM metallopeptidase with } \\
\text { thrombospondin type } 1 \text { motif, } 5\end{array}$ & 1.27 & 0.0213 & 208998_at & $\mathrm{UCP} 2$ & $\begin{array}{l}\text { uncoupling protein } 2 \\
\text { (mitochondrial, proton } \\
\text { carrier) }\end{array}$ & -1.12 & 0.0073 \\
\hline 236119_s_at & SPRR2G & small proline-rich protein $2 \mathrm{G}$ & 1.26 & 0.0082 & 225275_at & EDIL3 & $\begin{array}{l}\text { EGF-like repeats and } \\
\text { discoidin I-like domains } 3\end{array}$ & -1.11 & 0.0295 \\
\hline 203559_s_at & $\mathrm{AOCl}$ & amine oxidase, copper containing 1 & 1.25 & 0.0026 & 228108_at & PPM1L & $\begin{array}{l}\text { protein phosphatase, } \mathrm{Mg} 2+/ \\
\mathrm{Mn} 2+\text { dependent, } 1 \mathrm{~L}\end{array}$ & -1.11 & 0.0182 \\
\hline 205899_at & CCNA1 & cyclin A1 & 1.25 & 0.0079 & 202295_s_at & $\mathrm{CTSH}$ & cathepsin $\mathrm{H}$ & -1.1 & 0.0496 \\
\hline 223952_x_at & DHRS9 & $\begin{array}{l}\text { dehydrogenase/reductase } \\
\text { family) member } 9\end{array}$ & 1.25 & 0.0024 & 233289_at & - & - & -1.09 & 0.0384 \\
\hline 1557321_a_at & CAPN14 & calpain 14 & 1.23 & 0.0045 & 218807_at & VAV3 & $\begin{array}{l}\text { vav } 3 \text { guanine nucleotide } \\
\text { exchange factor }\end{array}$ & -1.08 & 0.0446 \\
\hline 238654_at & VSIG10L & $\begin{array}{l}\text { V-set and immunoglobulin domain } \\
\text { containing } 10 \text { like }\end{array}$ & 1.23 & 0.0045 & 219885_at & SLFN12 & schlafen family member 12 & -1.07 & 0.03 \\
\hline 216466_at & NAV3 & neuron navigator 3 & 1.22 & 0.0079 & 227148_at & PLEKHH2 & $\begin{array}{l}\text { pleckstrin homology domain } \\
\text { containing, family } \mathrm{H} \text { (with } \\
\text { MyTH4 domain) member } 2\end{array}$ & -1.05 & 0.0119 \\
\hline 242773_at & SLC5A1 & $\begin{array}{l}\text { solute carrier family } 5 \text { (sodium/ } \\
\text { glucose cotransporter), member } 1\end{array}$ & 1.22 & 0.0024 & 235683_at & SESN3 & sestrin 3 & -1.01 & 0.0255 \\
\hline 208539_x_at & SPRR2B & small proline-rich protein $2 \mathrm{~B}$ & 1.2 & 0.0048 & 208083_s_at & $\begin{array}{l}\text { ITGB6 } \\
\text { LOC100505984 }\end{array}$ & 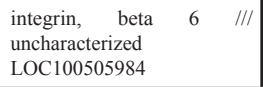 & -1 & 0.0443 \\
\hline 220723_s_at & CWH43 & $\begin{array}{l}\text { cell wall biogenesis } 43 \text { C-terminal } \\
\text { homolog (S. cerevisiae) }\end{array}$ & 1.2 & 0.0047 & 229553_at & PGM2L1 & phosphoglucomutase 2-like 1 & -1 & 0.0329 \\
\hline 235272_at & SBSN & suprabasin & 1.2 & 0.0068 & 218326_s_at & LGR4 & $\begin{array}{l}\text { leucine-rich repeat } \\
\text { containing G protein-coupled } \\
\text { receptor } 4\end{array}$ & -0.99 & 0.0223 \\
\hline 221667_s_at & HSPB8 & heat shock $22 \mathrm{kDa}$ protein 8 & 1.19 & 0.0036 & 228390_at & RAB30 & $\begin{array}{l}\text { RAB30, member RAS } \\
\text { oncogene family }\end{array}$ & -0.99 & 0.0373 \\
\hline 224367_at & BEX2 & brain expressed $\mathrm{X}$-linked 2 & 1.19 & 0.0346 & 242671_at & - & -- & -0.99 & 0.0402 \\
\hline 206199_at & CEACAM7 & $\begin{array}{l}\text { carcinoembryonic antigen-related } \\
\text { cell adhesion molecule } 7\end{array}$ & 1.14 & 0.0034 & 206488_s_at & CD36 & $\begin{array}{l}\text { CD36 molecule } \\
\text { (thrombospondin receptor) }\end{array}$ & -0.98 & 0.0076 \\
\hline 206714_at & ALOX15B & $\begin{array}{l}\text { arachidonate 15-lipoxygenase, } \\
\text { type B }\end{array}$ & 1.13 & 0.0185 & 241684_at & - & - & -0.96 & 0.0475 \\
\hline 218963_s_at & KRT23 & $\begin{array}{l}\text { keratin } 23 \text { (histone deacetylase } \\
\text { inducible) }\end{array}$ & 1.13 & 0.0036 & 242836_at & - & - & -0.96 & 0.0317 \\
\hline 211478_s_at & DPP4 & dipeptidyl-peptidase 4 & 1.12 & 0.0307 & 211922_s_at & CAT & catalase & -0.94 & 0.0188 \\
\hline 202086_at & MX1 & $\begin{array}{l}\text { myxovirus (influenza virus) } \\
\text { resistance 1, interferon-inducible } \\
\text { protein p78 (mouse) }\end{array}$ & 1.11 & 0.0061 & 233664_at & - & - & -0.94 & 0.0366 \\
\hline 206953_s_at & $\begin{array}{l}\text { LOC101927458 /// } \\
\text { LPHN2 }\end{array}$ & $\begin{array}{l}\text { uncharacterized LOC101927458 /// } \\
\text { latrophilin } 2\end{array}$ & 1.11 & 0.0106 & 233882_s_at & SEMA6D & $\begin{array}{l}\text { sema } \\
\text { transmembrane domain, } \\
(\mathrm{TM}) \text { and cytoplasmic } \\
\text { domain, (semaphorin) 6D }\end{array}$ & -0.94 & 0.0452 \\
\hline 220724_at & CWH43 & $\begin{array}{l}\text { cell wall biogenesis } 43 \text { C-terminal } \\
\text { homolog (S. cerevisiae) }\end{array}$ & 1.1 & 0.0122 & 201645_at & TNC & tenascin $\mathrm{C}$ & -0.93 & 0.01 \\
\hline
\end{tabular}

relative to genes involved in the development of different skin disorders (CNFN, CDSN, TGM1, ALOX12B, etc). In this regard, alterations in proteins of the differentiated and cornified layers of the skin (such as cornifelin, corneodesmosin, transglutaminase 1, alox12B, ABCA12 etc.), has been associated with various cutaneous pathologies in human, such as inflammatory diseases, i.e. psoriasis, eczema, dermatitis and ichthyosis [28-30]. This result agrees with the recent studies finding that the induction of IKK $\alpha$ has an important role in the pathogenesis of skin disorders that course with altered proliferation-differentiation equilibrium, such as psoriasis [8]. Moreover, microarrays analysis showed in HaCat-IKK $\alpha$ skin equivalents the upregulation of genes that are also upregulated in different types of ichthyosis (Table 1), and this is interesting, as several of the defects observed in IKK $\alpha$ mutant mice are similar to those manifested in human lamellar ichthyosis [3]. It is also noteworthy the differentially expressed genes found in HaCat- IKK $\alpha$ skin equivalents which are involved in the development of palmoplantar keratoderma, a heterogeneous group of disorders characterized by abnormal thickening of the palms and soles; being this phenotype consistent with the excesive differentiation displayed by the HaCat-IKK $\alpha$ skin equivalents.

Therefore, all these ocurrences reinforce the significance of our genetic profile studies and support the utility of our in vitro model of skin equivalents for studying the homeostasis and diseases of the skin. The relationship of IKK $\alpha$ overexpression with the development of different skin disorders and diverse types of cancer is an interesting issue to be investigated in future works. 
Altogether, our results suggest that the increased expression of IKK $\alpha$ in human keratinocytes induces features of malignancy such as altered differentiation properties, increased proliferative and clonogenic properties, augmented ability for invasive growth, induction of the expression of oncogenic proteins and increased extracellular matrix proteolytic activity. All these characteristics make keratinocytes overexpressing IKK $\alpha$ to be at a higher risk to develop skin cancer than control keratinocytes.

\section{MATERIALS AND METHODS}

\section{Plasmid constructs}

The $\beta$-Actin-Control construct (containing the empty vector) and the $\beta$-Actin-HA-IKK $\alpha$ construct (containing the HA-tagged-murine IKK $\alpha$ cDNA, under the control of the $\beta$-Actin promoter), were previously described [12]. Both constructs confer resistance to G418.

\section{Cells and culture conditions}

The HaCaT human keratinocyte cell line was grown in Dulbecco's modified Eagle's medium with Glutamax (Gibco-BRL, Gaithersburg, MD), supplemented with $10 \%$ FCS. HaCaT-Control cells (containing the $\beta$-ActinControl construct) and HaCaT-IKK $\alpha$ cells (containing the $\beta$-Actin-HA-IKK $\alpha$ construct) were previously described [12]. Cells were permanently transfected using the calcium phosphate method. Resistant colonies were selected using G418 $(0.45 \mathrm{mg} / \mathrm{ml})$. Pools of HaCat-IKK $\alpha$ cells (derived from approximately 60 colonies) were employed in these experiments. For proliferation assays cells were incubated for $1 \mathrm{~h}$ in presence of $10 \mathrm{mM} \mathrm{BrdU}$.

\section{Colony forming assay}

A total of 3 and $6 \times 10^{2}$ cells were seeded per duplicate in DMEM-10\% FCS in p100 plates. Medium was replaced every 4 days. Cells were fixed and stained with crystal violet. Experiments were performed three times.

\section{Cell proliferation assay}

$5 \times 10^{4}$ cells/p60 were seeded in complete medium (DMEM-10\% FCS) . At 24, 48, 72 and $96 \mathrm{~h}$ cells were trypsinized and counted. Three experiments per triplicate were performed.

\section{Generation of skin equivalents}

Primary human dermal fibroblasts were obtained from skin biopsies of health donors and were grown in DMEM containing $10 \%$ fetal calf serum, $2 \mathrm{mM}$ glutamine, and epidermal growth factor $(10 \mathrm{ng} / \mathrm{ml})$. Donors provided informed consent for biopsy. Permission was obtained for specimens taken from organ donors. Skin equivalents were generated as described [31]. Briefly, $2.5 \mathrm{ml}$ of fibrinogen solution (from cryoprecipitated pig blood) were added to $5 \mathrm{ml}$ of keratinocyte growth medium containing $3 \times 10^{4}$ dermal fibroblasts. Immediately later, $0.5 \mathrm{ml}$ of $25 \mathrm{mM}$ $\mathrm{Cl}_{2} \mathrm{Ca}$, with $9 \mathrm{IU}$ of bovine thrombin (Sigma-Aldrich Co., St. Louis) was added. The mixture was placed on polycarbonate inserts ( $4 \mu \mathrm{M}$ porous) in a 6-well culture plate (Corning Costar Corp., Cambridge, MA) and allowed to solidify at $37^{\circ} \mathrm{C}$ for $45 \mathrm{~min}$; after that, $10^{6}$ $\mathrm{HaCaT}$ cells were seeded on the fibrin matrix and grown to confluence. After reaching confluence the skin equivalent was raised to the air-liquid interface for variable time periods (up to 12 days) to generate a stratified epidermis. For proliferation assays skin equivalents were grown $1 \mathrm{~h}$ in presence of $10 \mathrm{mM} \mathrm{BrdU}$.

\section{Histology and immunohistochemistry}

Skin equivalents were fixed in $10 \%$ buffered formalin and embedded in paraffin. Sections were stained with H\&E and histopathological evaluation of skin equivalents was performed by two specialists in pathological anatomy: MJFA, specialized in human pathology and $\mathrm{AB}$, a veterinarian expert in animal pathology. Immunostaining was performed using antibodies against IKKa NB-100-56704 (Novus Biologicals, Cambridge UK); IKKa sc-7182 (Santa Cruz Biotechnology, Inc. Heidelberg, Germany); IKKa 556532, Plakoglobin (BD Bioscience, NJ, USA); Involucrin, Filaggrin (Covance, CA, USA); BrdU (Roche, Mannheim, Germany). Sections were incubated with a biotinylated secondary antibody, and then with streptavidin conjugated to horseradish peroxidase (DAKO A/S, Glostrp, Denmark). Antibody localization was determined using 3,3-diaminobenzidine (DAB) in $\mathrm{H}_{2} \mathrm{O}$ (Vector Laboratories; Burlingame, CA, USA).

Pressure cooker with DAKO target retrieval solution ph9.0 (DAKO) was employed for antibodies detection.

\section{Western blot analysis}

Protein extracts were obtained from the epidermal compartment of skin equivalents. Total protein extracts $(40 \mu \mathrm{g})$ were subjected to SDS/PAGE. The separated proteins were transferred to nitrocellulose membranes (Amersham, Arlington Heights, IL) and probed with antibodies against IKKa NB-100-56704 (Novus Biologicals); HA (Cell Signaling Technology, USA); Snail (Abcam, Cambridge, UK); Cyclin D1 (NeoMarkers, Fremont, CA, USA); Podoplanin, Actin (Santa Cruz Biotechnology); MMP-9 (Merck Millipore, Darmstadt, Germany). In all cases samples were subjected to luminography with the Supersignal West Pico Chemiluminescent Substrate (Pierce Biotechnology, Inc., Illinois, USA). 


\section{Gelatin zymography}

Gelatin zymography was performed as described [32]. $20 \mu \mathrm{g}$ of protein extracts from supernanatants were subjected to SDS/PAGE with $0.1 \%$ gelatin (SigmaAldrich, MO, USA). Gel were stained with $0.25 \%$ Coomasie-Blue R-250 in methanol:acetic:water (5:1:5) and destained in $7.5 \%$ acetic acid.

\section{Microarrays of skin equivalents}

Total RNA was isolated from the epidermal compartment of skin equivalents using TRIzol (Molecular Research Center Inc., Cincinnati, OH, USA) following manufacturer's instructions and DNA was eliminated using a DNAse column kit (Qiagen). HG-U133_Plus_2 arrays were used (Afymetrix) and annotations were updated to the last available version (June 2016). Data were normalized using RPA and processed using limma (Bioconductor). Genes with a foldchange of at least 1.5 and a $p$ value of less than 0.05 were considered as regulated. Gene lists with up- or downregulated genes were submitted to ToppGene (as ranked lists) [33] or to JMP Enrichr (as fuzzy lists) [34] for enrichment analysis based on functional annotations.

\section{ACKNOWLEDGMENTS AND FUNDING}

We thank Marta Ortiz-Martín for invaluable technical assistance; Almudena Holguín, Marta García, Fernando Larcher for assistance in the establishment of skin equivalents; and Pilar Hernández and Federico Sánchez-Sierra for histological assistance. The study was funded by the following: AES grants ISCIIIFIS PI13/02580 and PI14/01403 to M.L. Casanova and A. Ramírez respectively; grant 1.010.511 (Fundación Banco de Santander-Universidad Alfonso X el Sabio) Fernández-Aceñero; Comunidad Autónoma de Madrid grant S2010/BMD-2470 (Oncocycle Program) to JMP and CIEM13-4E-1944; to JMP AES grants ISCIII-RETIC RD06/0020/0029 and RD12/0036/0009 to JMP.

\section{CONFLICTS OF INTEREST}

The authors declare no conflicts of interest.

\section{REFERENCES}

1. Gareus R, Huth M, Breiden B, Nenci A, Rosch N, Haase I, Bloch W, Sandhoff K, Pasparakis M. Normal epidermal differentiation but impaired skin-barrier formation upon keratinocyte-restricted IKK1 ablation. Nat Cell Biol. 2007; 9:461-469.

2. Hu Y, Baud V, Delhase $M$, Zhang $P$, Deerinck $T$, Ellisman M, Johnson R, Karin M. Abnormal morphogenesis but intact IKK activation in mice lacking the IKKalpha subunit of IkappaB kinase. Science. 1999; 284:316-320.
3. Li Q, Lu Q, Hwang JY, Buscher D, Lee KF, IzpisuaBelmonte JC, Verma IM. IKK1-deficient mice exhibit abnormal development of skin and skeleton. Genes Dev. 1999; 13:1322-1328.

4. Takeda K, Takeuchi O, Tsujimura T, Itami S, Adachi O, Kawai T, Sanjo H, Yoshikawa K, Terada N, Akira S. Limb and skin abnormalities in mice lacking IKKalpha. Science. 1999; 284:313-316.

5. Ghosh S, Karin M. Missing pieces in the NF-kappaB puzzle. Cell. 2002; 109:S81-96.

6. Hayden MS, Ghosh S. Signaling to NF-kappaB. Genes Dev. 2004; 18:2195-2224.

7. $\mathrm{Hu}$ Y, Baud V, Oga T, Kim KI, Yoshida K, Karin M. IKKalpha controls formation of the epidermis independently of NF-kappaB. Nature. 2001; 410:710-714.

8. Cho KA, Kim JY, Woo SY, Park HJ, Lee KH, Pae CU. Interleukin-17 and Interleukin-22 Induced Proinflammatory Cytokine Production in Keratinocytes via Inhibitor of Nuclear Factor kappaB Kinase-alpha Expression. Ann Dermatol. 2012; 24:398-405. doi: 310.5021/ ad.2012.5024.5024.5398. Epub 2012 Nov 5028.

9. Park E, Zhu F, Liu B, Xia X, Shen J, Bustos T, Fischer SM, $\mathrm{Hu}$ Y. Reduction in IkappaB kinase alpha expression promotes the development of skin papillomas and carcinomas. Cancer Res. 2007; 67:9158-9168.

10. Liu B, Xia X, Zhu F, Park E, Carbajal S, Kiguchi K, DiGiovanni J, Fischer SM, Hu Y. IKKalpha is required to maintain skin homeostasis and prevent skin cancer. Cancer Cell. 2008; 14:212-225.

11. Alameda JP, Moreno-Maldonado R, FernandezAcenero MJ, Navarro M, Page A, Jorcano JL, Bravo A, Ramirez A, Casanova ML. Increased IKKalpha Expression in the Basal Layer of the Epidermis of Transgenic Mice Enhances the Malignant Potential of Skin Tumors. PLoS One. 2011; 6:e21984.

12. Moreno-Maldonado R, Ramirez A, Navarro M, FernandezAcenero MJ, Villanueva C, Page A, Jorcano JL, Bravo A, Llanos Casanova M. IKKalpha enhances human keratinocyte differentiation and determines the histological variant of epidermal squamous cell carcinomas. Cell Cycle. 2008; 7:2021-2029.

13. Carretero M, Del Rio M, Garcia M, Escamez MJ, Mirones I, Rivas L, Balague C, Jorcano JL, Larcher F. A cutaneous gene therapy approach to treat infection through keratinocyte-targeted overexpression of antimicrobial peptides. Faseb J. 2004; 18:1931-1933.

14. Alameda JP, Fernandez-Acenero MJ, Moreno-Maldonado R, Navarro M, Quintana R, Page A, Ramirez A, Bravo A, Casanova ML. CYLD regulates keratinocyte differentiation and skin cancer progression in humans. Cell Death Dis. 2011; 2:e208; doi:210.1038/cddis.2011.1082.

15. Albanese C, Wu K, D'Amico M, Jarrett C, Joyce D, Hughes J, Hulit J, Sakamaki T, Fu M, Ben-Ze'ev A, Bromberg JF, Lamberti C, Verma U, et al. IKKalpha regulates mitogenic signaling through transcriptional 
induction of cyclin D1 via Tcf. Mol Biol Cell. 2003; 14:585-599.

16. Deryugina EI, Quigley JP. Matrix metalloproteinases and tumor metastasis. Cancer metastasis reviews. 2006; 25:9-34.

17. Jorda M, Olmeda D, Vinyals A, Valero E, Cubillo E, Llorens A, Cano A, Fabra A. Upregulation of MMP-9 in MDCK epithelial cell line in response to expression of the Snail transcription factor. J Cell Sci. 2005; 118:3371-3385.

18. Scholl FG, C G, Quintanilla M. Ectopic expression of PA2.26 antigen in epidermal keratinocytes leads to destabilization of adherens junctions and malignant progression. Lab Invest. 2000; 80:1749-1759.

19. Wicki A, F L, Fau WN, B H, D K, Christofori G. Tumor invasion in the absence of epithelial-mesenchymal transition: podoplanin-mediated remodeling of the actin cytoskeleton. Cancer Cell. 2006; 9:261-272.

20. Lawrence T, Bebien M, Liu GY, Nizet V, Karin M. IKKalpha limits macrophage NF-kappaB activation and contributes to the resolution of inflammation. Nature. 2005; 434:1138-1143.

21. Mancino A, Habbeddine M, Johnson E, Luron L, Bebien M, Memet S, Fong C, Bajenoff M, Wu X, Karin M, Caamano J, Chi H, Seed M, et al. I kappa B kinase alpha (IKKalpha) activity is required for functional maturation of dendritic cells and acquired immunity to infection. Embo j. 2013; 32:816-828.

22. Brandl M, Seidler B, Haller F, Adamski J, Schmid RM, Saur D, Schneider G. IKK(alpha) controls canonical TGF(ss)-SMAD signaling to regulate genes expressing SNAIL and SLUG during EMT in panc1 cells. J Cell Sci. 2010; 123:4231-4239.

23. Lu Y, Wahl LM. Production of matrix metalloproteinase-9 by activated human monocytes involves a phosphatidylinositol-3 kinase/Akt/IKKalpha/NF-kappaB pathway. J Leukoc Biol. 2005; 78:259-265.

24. Alameda JP GM, Ramírez A, Navarro M, Page A, Suárez-Cabrera C, Fernández MG, Mérida JR, Paramio JM, García-Fernández RA, Fernández-Aceñero MJ, and Casanova ML. Deciphering the role of nuclear and cytoplasmic IKKalpha in skin cancer. Oncotarget. 2016; 7:29531-47. doi: 10.18632/oncotarget.8792.

25. Luo JL, Tan W, Ricono JM, Korchynskyi O, Zhang M, Gonias SL, Cheresh DA, Karin M. Nuclear cytokine- activated IKKalpha controls prostate cancer metastasis by repressing Maspin. Nature. 2007; 446:690-694.

26. Abdel-Latif MM, Kelleher D, Reynolds JV. Molecular mechanisms of constitutive and inducible NF-kappaB activation in oesophageal adenocarcinoma. Eur J Cancer. 2015; 51:464-472.

27. Nottingham LK, Yan CH, Yang X, Si H, Coupar J, Bian Y, Cheng TF, Allen C, Arun P, Gius D, Dang L, Van Waes C, Chen Z. Aberrant IKKalpha and IKKbeta cooperatively activate NF-kappaB and induce EGFR/AP1 signaling to promote survival and migration of head and neck cancer. Oncogene. 2014; 33:1135-1147.

28. Madison KC. Barrier function of the skin: "la raison d'etre" of the epidermis. J Invest Dermatol. 2003; 121:231-241.

29. D'Amico F, Skarmoutsou E, Granata M, Trovato C, Rossi GA, Mazzarino MC. S100A7: A rAMPing up AMP molecule in psoriasis. Cytokine Growth Factor Rev. 2016.

30. Richard G, Bale SJ. Autosomal Recessive Congenital Ichthyosis. In: Pagon RA, Adam MP, Ardinger HH, Wallace SE, Amemiya A, Bean LJH, Bird TD, Fong CT, Mefford HC, Smith RJH, Stephens K, eds. GeneReviews(R). (Seattle (WA): University of Washington, Seattle University of Washington, Seattle. All rights reserved.).

31. Del Rio M, Larcher F, Serrano F, Meana A, Munoz M, Garcia M, Munoz E, Martin C, Bernad A, Jorcano JL. A preclinical model for the analysis of genetically modified human skin in vivo. Hum Gene Ther. 2002; 13:959-968.

32. Heussen C Fau - Dowdle EB, Dowdle EB. Electrophoretic analysis of plasminogen activators in polyacrylamide gels containing sodium dodecyl sulfate and copolymerized substrates. Anal Biochem. 1980; 102:196-202.

33. Chen J, Bardes EE, Aronow BJ, Jegga AG. ToppGene Suite for gene list enrichment analysis and candidate gene prioritization. Nucleic Acids Res. 2009; 37:W305-311.

34. Kuleshov MV, Jones MR, Rouillard AD, Fernandez NF, Duan Q, Wang Z, Koplev S, Jenkins SL, Jagodnik KM, Lachmann A, McDermott MG, Monteiro CD, Gundersen GW, et al. Enrichr: a comprehensive gene set enrichment analysis web server 2016 update. Nucleic Acids Res. 2016; 44:W90-97. 